\title{
Review of Edurne Garrido-Anes (2020) A Middle English Version of the Circa Instans, Middle English Texts Series, 59. Heidelberg: Winter Verlag, pp. 209. ISBN 978-3-8253-4766-6
}

\author{
María José Esteve-Ramos ${ }^{1}$ - (i) https://orcid.org/0000-0003-4935-2413 \\ Universitat Jaume I \\ Dpt d'Estudis Anglesos, Facultat de Ciències Humanes i Socials, 12.071 Castelló (Spain)
}

Medical and scientific manuscripts have been the interest of scholarly attention in recent decades and as a natural consequence, editions of unstudied material have flourished (Alonso-Almeida, 2014 or Marqués-Aguado, T. et alii, 2008, among others). This book is a Middle English edition of one of the most popular works circulating in the late medieval England, known as Circa Instans. This book presents a revised edition of the text found in CUL MS Es 1.13. ff 1r-91v, housed in the Cambridge University Library.

The present work is structured presenting the following sections: abbreviations, manuscript sigla, manuscripts, and a list of figures followed by the introduction, commentary, glossary and two appendixes, containing comparative table of entries and marginalia. The introduction is subdivided in several sections, which delve into the sources of the texts, its analogue versions and the circulation and impact of the English version, object of the present edition. The exposition of the objectives is very clear, successfully presenting and justifying the necessity of an edition of the English version. This section provides with the necessary background and context, starting with the history of the text. The Circa Instans is attributed to Matthaeus Platearius, a physician of the wellknown Salernitan School, and it is a treatise composed in the mid 12 $2^{\text {th }}$ century, known under the name of Liber de Simplici Medicina. This work was influential during at least four centuries, as it is attested by the number of surviving copies and in different languages. It had a significant influence until the time when chemical remedies were introduced by Paracelsus, transiting to a new era where plant remedies were no longer the main source for healing. As a consequence, textual production of herbals decreased enormously, and the Circa Instans stopped being copied. It had been, until then, one of the most relevant texts in the medieval medical lore, having an important artistic, medical and linguistic relevance.

The importance of the Salernitan School and tradition, where sources from Arabic and Hebrew were translated occupied the following pages. This school was the clear referent for Universities and medical practitioners. In this section, the author introduces and explains the context related to history of medicine, mainly related to the theories of the four humours and the theory of degrees and how medicines allocated these properties with a quality, all with the ultimate purpose of restoring the balance (known as eucrasis) which resulted in health. These assumptions were the basis of medieval medicine. It ends with a detailed explanation of all the related texts and 
sources, completing an excellent section which accomplishes to give the reader a thorough and precise narrative of the textual relationships.

We are now presented with the analogues and influence of the Latin version of the Circa Instans, where the evolution of botanical treatises is explained, as herbaria had a fundamental role in medieval medical compendia. These herbals would, in many cases, adopt the form of glossaries, where alphabetical arrangement was common, although the order of the different entries would not necessarily correspond to the expectation of an A-Z arrangement (Keiser, 2008 :302). Another common feature we find in herbals of this period was that it was common for miscellaneous volumes to complete or complement the information about herbs and remedies with different treatises. Thus, shorter treatises missing a few names of plants would be complemented by another in the same volume which would contain those. To finish with the information about the evolution of the herbals, we read that the Circa Instans reached the times of printing, materialized in examples such as Robert Thorton's Herbal or in the Grete Herball. Another well-known afterlife is Bancke's Herball (xxiii) (1525) which is also known as Askham's Herbal or Wyer's Herbal and it could also be based on the Circa Instans, although the first part of this work is drawn from another popular Herbal known as Agnus Castus, as pointed out by Brodin (1950) in the only existing edition -so far- of this last text. Finally, the last work that refers back to Platearius is the English Physician, 1652, by Nicholas Culpeper. This is probably the end of the treatise in terms of its medical function. However, this material gained renewed attention in the $19^{\text {th }}$ century, when philologists and historians began to produce critical studies on them.

Following and complementing the section before, the reader can now find out about the information related to the previous research on the Middle English copy and its transmission. The presence of the Middle English work was identified in library catalogues and databases. Criteria for the identification of the text are also explained, together with the social and authorial remarks which takes us to a world of practitioners, copyist and users of the text. There are more than fifty copies of the CI with suspected or proved connection with England that have been identified. Nobility and also the Monarchy very frequently had a copy of the most popular Herbals. In fact, Queen Philippa of Hainault, the wife of Edward III owned a copy of the work, which was beautifully ornamented. A work of this type is also a reflection of a complex series of translations and transmission channels. The fluidity of these texts is characteristic of medieval manuscripts, which is even more so in the case of medical tracts. Different audiences came acquainted with, most probably, the vernacular version of Circa Instans. The author refers at this point to the three groups of texts belonging to the classification as they correspond to three distinct translations or compilations derived from the Latin one. Reference is made in this section to the fluidity of textual transmission, resulting in adaptations which could be useful and recognizable for both, experts and lay audiences. In this sense, the function of the work conditioned the form under we could reach this material.

The study of the dialectal distribution fills the next pages. The Linguistic Atlas of Late Mediaeval English (LALME) has not been used; however, the author has deployed its methodology to create linguistic profiles for the scribes, and has also used the fit-technique to locate dialectal features in a map. As a result, the evidence points towards central and Eastern Midlands in its majority, also showing traces of southwestern and one that shows northern origin.

The following section deals with the criteria for selecting CUL MS Es 1.13., and the different aspects that have been considered to choose this copy for this edition are clearly and thoroughly explained. On these final sections of the introduction, we can see a philologist at work: she masters the topic and clearly engages in the joys of elaborating, once and again, on the intricate connection of the different copies, their attributes, functions and 
transmission. The reader is, at this point, in a dialogue with the author. We find now several paragraphs in reference to the Latin model. The material hereby discussed unveils a variety and number of manuscripts accounting for a great complexity of textual relationships. All in all, the author manages to successfully establish these relationships and presents the most significant variants in order to compare them with the selected manuscript. A detailed description of the chosen manuscript follows, as expected in this kind of publication, comprising all the sections referring to physical description, script and punctuation, denotation and also to the contents of the codex. This last aspect is one which I find particularly interesting as it accounts for the recognition that all materials in a miscellaneous volume add valuable information not only about the text, but of the reasons why and how these materials came up to be together, a fact that can be meaningful in establishing a dialogue of the text under study and its companions (Esteve-Ramos, 2020: 189). As in other similar works like the Agnus Castus Herbal, the Circa Instans is found together with recipes, urine tracts, a treatise on agriculture by Nicollas Bollard, a tract on dyeing, a tract on alchemical recipes, and the Philosopher's Stone, another popular alchemical tract. The importance of this section relies on the valuable information it provides about its function: as the author says, it helps us to identify a non-professional ownership, as the use of herbaria could be extended beyond medical practice and also be central in agriculture or household remedies.

A description of the marks of ownership and later history fill the next pages, in which the possible provenance of the material is identified, showing a strong connection of the dialects present in the volume and the county of Norfolk. This is followed by an extensive section on dialectal localization, in which the methodology is explained in detail. There are ample data to showing the dialectal varieties in the edited text, which reflect a tendency to more standarized forms, in line with the concept of what standard meant in that time and that particular context. To finish with the introduction, we find the editorial policy. As expected, the author introduces the section explaining the decisions and criteria followed by the current edition, and lists the conventions and abbreviations accordingly. After this, the reader finds the Circa Instans in all its glory, carefully edited. After the text, two sections deserve our attention: the commentary and the glossary. Both sections offer invaluable information about the linguistic, historical and cultural insights of the text, and reflect the painstaking work of the editor. The commentary provides specific explanations that deal with technical concepts, cultural and conceptual references that may pose some problems or may diminish the overall understanding of the text. Many references to aspects related to the historical background of the medical science and profession are present, which the reader will definitely find very useful. The glossary is rich in technical terms, which abound in this type of text. Also interesting is the brief reference to their provenances that the author explains at the beginning of this section, which show a significant percentage of non-native words. We find, at the end of the book, the appendices, followed by the bibliography, which is very complete, as the whole book, which is a highly recommendable piece of scholarship.

In sum, the work is extensively documented and reflects the love for detail and perfection of a well-trained philologist. This edition of the English version of the Circa Instans is, no doubt, a remarkable philological work, and it deserves all the credit this reviewer can humbly provide. It is to become a reference for the lover and specialists of philology and history of medicine alike, and a must for the shelves of every University.

\section{Declaration of conflicting interests}

The author(s) declared no potential conflicts of interest with respect to the research, authorship, and/or publication of this article. 


\section{Funding}

This review forms part of the project 'Repertori i estudi dels exempla medievals documentats a les literatures catalana i anglesa' ('Catalogue and study of medieval exempla recorded in Catalan and English literatures') (UJI-B2020-04) and has been produced at Universitat Jaume I of Castellón, Spain.

\section{About the author}

María José Esteve Ramos obtained her doctoral thesis (European) about the diachronic evolution of medical language in the field of ophthalmology in 2003. She teaches Old and Middle English at Universitat Jaume I, where she has been a senior lecturer since 2009. She collaborates as a full member of MuStE since 2006, and is currently working in the Coruña Corpus Project. She is a member of the Board of the Catalan Society for the History of Science. Also, she has been director of IULMA (Instituto Interuniversitario de Lenguas Modernas Aplicadas) for six years and has been vicedean of the Humanitites Faculty until July 2018. She has been visiting the ASNC department in Cambridge as Honorary Researcher in 2016., and she has visited the University of Glasgow several times as a visiting researcher. She has organised several conferences, such as the SELIM (Spanish Society for English Medieval Language and Literature) conference in 1995 and 2014, the AHLM (Asociación Española de Lengua y Literatura Inglesa Medieval) in 1996 among many others. Her main research interests are the evolution of scientific English and its specialised lexicon, medieval texts and manuscripts, corpus linguistics and etymology.

\section{References}

Anonymous. (1526). The Grete Herball [...] translated out of pe Frensshe into Englysshe. London: Peter Treueris.

Alonso-Almeida, F. (2014) A Middle English Medical Remedy Book Edited from Glasgow University Library MS Hunter 185, Middle English Texts, 50. Heidelberg: Winter Verlag.

Brodin, G. (1950). Agnus Castus, A Middle English Herbal: Reconstructed from Various Manuscripts. Uppsala, Lundequistska Bokhandeln.

Culpeper, N. (1652). The English Physician. London: W. Bentley

Esteve-Ramos, M. J. (2020) "The Effects of Manuscripts Contexts in Textual Transmission of Scientific Material: a Comparison of Source from the Sloane Collection.” In: Bellmunt, M \& J. Mahiques. Literature, Science and Religion. Textual Transmission and Translation in Medieval and Early Modern Europe. Kassel: Reichenberger.

Keiser, G.R. (2008). "Vernacular Herbals: A Growth Industry in Late Medieval England”. In M. Conolly \& L.R. Mooney (eds) Design and Distribution of Late Medieval England. Rocherster: Boydell \& Brewer: 291-308

Marqués-Aguado, T., Miranda-García, A., and González Fernández-Corugedo, S. (2008). Benvenutus Grassus, The Middle English Ophthalmic Treatise on the Use of the Eye in G.UL.MS Hunter 513 (ff. 1r-37r): An annotated Edition and Study. Málaga: Servicio de Publicaciones de la Universidad de Málaga.

McIntosh, A., Samuels, M. L., and Benskin, M. (1986). A Linguistic Atlas of Late Mediaeval English (LALME). Aberdeen: Aberdeen University Press. 